\title{
Efektivitas nature sound terhadap penurunan insomnia
}

\author{
William Shakespeare ${ }^{a, 1^{*}}$, Widyastutib,2, Ahmad Ridfah ${ }^{\mathrm{c}, 3}$ \\ a,b,cFakultas Psikologi, Universitas Negeri Makassar, Makassar \\ *1whshakespeare091096@gmail.com; ${ }^{2}$ widya_prasthya@yahoo.com; ${ }^{3}$ ahmad.ridfah@unm.ac.id \\ *Correspondent Author
}

Received: 01-09-2020

Revised: 14-06-2021

Accepted: 26-10-2021

KATAKUNCI

insomnia;

insomnia severity index scale; nature sound

\section{KEYWORDS}

insomnia;

insomnia severity index scale;

nature sound

\section{ABSTRAK}

Tidur merupakan kebutuhan yang sangat penting karena memiliki manfaat yang besar bagi individu. Sementara, terdeteksi sebanyak $30 \%$ penduduk di dunia menderita insomnia yang merupakan gangguan tidur dengan penderita terbanyak dibandingkan dengan gangguan tidur lainnya. Begitupula di Indonesia sendiri terdapat sebanyak $10 \%$ penduduk mengalami insomnia. Dengan demikian dibutuhkan suatu intervensi untuk mengatasi permasalahan tersebut, dan nature sound diasumsikan merupakan salah satu alternatif untuk mengatasinya. Oleh karena itu, tujuan penelitian ini yaitu untuk mengetahui pengaruh pemberian nature sound terhadap penurunan insomnia. Penelitian ini menggunakan metode eksperimen kuasi dengan desain one group pretest-posttest. Sampel pada penelitian ini adalah 12 orang dewasa awal yang memiliki usia 21-24 tahun, memiliki gangguan insomnia, berstatus sebagai mahasiswa dan pegawai yang berdomisili di kota Makassar. Gangguan insomnia pada penelitian ini diukur dengan menggunakan Insomnia Severity Index (ISI). Teknik analisis data yang digunakan dalam penelitian ini adalah uji Wilcoxon yang dioperasikan melalui aplikasi SPSS 25.0 for windows. Hasil uji hipotesis pada penelitian ini menunjukkan ada perbedaan tingkat insomnia sampel saat sebelum mendengarkan nature sound dengan setelah mendengarkan nature sound. Selanjutnya penelitian ini menyimpulkan bahwa mendengarkan nature sound dapat menurunkan tingkat insomnia individu.

\section{The effectiveness of the sound of nature in reducing insomnia}

Sleep is an essential need because it has excellent benefits for individuals. Meanwhile, it was detected that 30\% of the world's population suffered from insomnia, which is a sleep disorder with the most sufferers compared to other sleep disorders. Likewise, in Indonesia alone, $10 \%$ of the population suffered from insomnia. Thus, an intervention is needed to overcome these problems: the sound of nature is assumed to be an alternative to overcome them. Therefore, this study aimed to determine the effect of providing the sound of nature to decrease insomnia. This study used a quasi-experimental method with a one-group pretest-posttest design. The sample in this study were 12 early adults at the age of 21-24 years, had insomnia disorders, were students and employees who lived in Makassar. Insomnia disorders in this study were measured using the Insomnia Severity Index (ISI). The data analysis technique used in this study is the Wilcoxon test operated through the SPSS 25.0 Software for Windows. In this study, the 
hypothesis test results showed different levels of insomnia to the samples before and after listening to the sound of nature. Furthermore, this study concluded that listening to the sounds of nature can reduce an individual's level of insomnia.

This is an open-access article under the CC-BY-SA license.

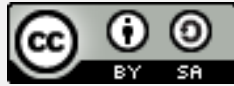

\section{Pendahuluan}

Individu memerlukan tidur dikarenakan tidur merupakan kebutuhan yang paling dasar mahluk hidup yang harus terpenuhi. Curcio, Ferrara, dan Gennaro (2006) mengemukakan bahwa tidur adalah perilaku yang akan terus dilakukan individu secara terus menerus. Di sisi lain tidur juga berguna untuk kelangsungan hidup setiap individu (Kozier, 2004) dalam rangka memaksimalkan kesehatan, ataupun kualitas kehidupan setiap individu (Potter \& Perry, 2006). Sesuai dengan yang disampaikan oleh Mass (2002) bahwa bahaya kekurangan tidur menyebabkan kinerja menjadi tidak maksimal, penurunan pendapatan, kecelakaan, menimbukan sakit dan penyakit, bahkan dapat berujung pada kematian. Begitupula, pola tidur yang buruk dapat berakibat pada gangguan keseimbangan fisiologis dan psikologis seperti penurunan ketelitian, kecekatan, fokus, dan kemampuan memori individu. Artinya, tidur memiliki manfaat sebagai proses pertumbuhan dan perbaikan fungsi-fungsi memori.

Tidur merupakan kebutuhan yang sangat penting karena memiliki manfaat yang besar bagi individu, akan tetapi tidak dapat dipungkiri masih didapati individu yang tidak memiliki tidur yang baik (kuantitas dan kualitas), dan salah satu faktor penyebabnya adalah gangguan tidur. PPDGJ (Maslim, 2013) mengemukakan bahwa penyakit atau gangguan tidur sendiri terbagi menjadi beberapa penyakit, misalnya night terror, nightmare, sleep paralyzed, sleep walking, hypersomnia, dan insomnia. Berdasarkan semua gangguan tidur tersebut, gangguan tidur yang paling banyak diderita oleh manusia adalah insomnia. Penyakit atau gangguan tidur ini adalah jenis penyakit yang terdengar biasa saja, namun sebenarnya sangat berbahaya karena penyakit ini dapat menjadi penyebab berbagai penyakit lain yang serius. Hal ini sesuai dengan yang disampaikan Maslim (2013), bahwa gangguan tidur insomnia adalah gangguan tidur yang paling banyak diderita oleh semua kalangan usia, mulai dari anak-anak hingga lansia. Artinya, semua level usia berkemungkinan menderita insomnia dibandingkan dengan gangguan tidur lainnya.

Istilah insomnia banyak diterjemahkan dengan berbagai cara di dalam literatur medis ataupun secara popular. Insomnia paling sering didefinisikan sebagai laporan individu tentang kesulitan tidur (Roth, 2007). Sathivel dan Setyawati (2017) mengemukakan bahwa insomnia adalah gangguan tidur yang ditandai dengan gejala kesulitan untuk memulai tidur dan mempertahankan tidur yang menyebabkan penurunan kesehatan dan gangguan emosi. Insomnia juga berkaitan dengan adanya lantensi tidur yang lama, sering terbangun di malam hari, atau periode terjaga yang berkepanjangan selama periode tidur atau bahkan sering terbangun (Sateia, Doghramji, Hauri, \& Morin, 2000). Maslim (2013) mengemukakan bahwa di dalam DSM-V insomnia didefinisikan sebagai gangguan kesulitan untuk memulai tidur, mempertahankan tidur, atau kualitas tidur buruk yang dialami individu paling kurang selama tiga bulan terakhir atau bahkan lebih. Diagnosis sebagai insomnia kronik ditegakkan jika keluhan tersebut dirasakan lebih dari tiga bulan. Selanjutnya Sathivel dan Setyawati (2017) mengemukakan bahwa insomnia dapat diklasifikasikan dalam beberapa kelompok, yaitu berdasarkan gejala, durasi dan penyebab.

Model kognitif menjelaskan insomnia sebagai gangguan hyperarousal yang dialami individu sepanjang hari. Hyperarousal tersebut dapat menunjukan dirinya sebagai keadaan 
hypervigilance di siang hari dan kesulitan memulai serta mempertahankan tidur di malam hari (Bonnet, \& Arand, 1995; Stepanski, Zorick, Roehrs, Young, \& Roth, 1988). Maslim (2013) menjelaskan insomnia berdasarkan gejala diantaranya mengalami kesulitan untuk tetap tidur, sulit tidur, tidur non-restoratif. Berdasarkan durasi, maka insomnia dapat digolongkan menjadi insomnia akut, kronis dan transien. Insomnia sementara berlangsung dalam waktu beberapa hari hingga seminggu, insomnia akut berakhir antara tiga minggu sampai enam bulan sedangkan insomnia kronis berlangsung selama bertahun-tahun pada suatu waktu. Selanjutnya insomnia berdasarkan penyebab dibagi menjadi dua, insomnia primer dan insomnia sekunder. Insomnia primer berarti bahwa seseorang mengalami masalah tidur yang tidak terkait langsung dengan masalah kesehatan lainnya. Di sisi lain, insomnia sekunder berarti bahwa individu memiliki masalah tidur karena faktor yang lain, seperti kondisi kesehatan (depresi, arthritis asma, kanker, atau mulas), rasa sakit dan mengomsumsi obat-obatan atau zat seperti alkohol.

Kesimpulan dari National Institutes of Health (NIH) State-of-the-Science Conference yang diadakan pada bulan Juni 2005 menunjukkan bahwa penambahan persyaratan diagnostik yang mencakup gangguan atau kesusahan siang hari yang dirasakan sebagai fungsi dari gejala insomnia menghasilkan sekitar $10 \%$ prevalensi insomnia (National Institutes of Health, 2005). Dengan demikian pada akhirnya, penerapan kriteria diagnostik yang lebih ketat, seperti Manual Diagnostik dan Statistik Gangguan Mental, Edisi Keempat (DSM-IV), yang mencakup persyaratan tambahan bahwa gejala insomnia bertahan setidaknya selama 1 bulan dan tidak secara eksklusif terjadi dengan adanya gangguan tidur lain, gangguan mental, atau efek fisiologis langsung dari sub sikap atau kondisi medis, menghasilkan perkiraan prevalensi saat ini sekitar 6\% (American Psychiatric Association, 1987).

Beberapa faktor risiko yang teridentifikasi dengan baik untuk insomnia dilaporkan oleh National Institutes of Health (2005), bahwa usia dan jenis kelamin adalah faktor risiko demografis yang paling jelas diidentifikasi, dengan peningkatan prevalensi pada wanita dan orang dewasa yang lebih tua. Selain itu, kondisi medis komorbiditas juga merupakan kontributor yang signifikan terhadap peningkatan prevalensi insomnia pada orang tua. Sementara pada wanita, insomnia lebih sering terjadi dengan onset menstruasi dan menopause (Johnson, Roth, Schultz, \& Breslau, 2006). Begitupula gangguan kesehatan mental (Susanti, 2015), gangguan psikiatri (Ford, \& Kamerow, 1989), gangguan medis komorbid (Katz, \& McHorney, 1998; Munir, 2015), kerja malam atau shift yang bergilir (Roth, 2007), stres, kecemasan dan depresi, obat-obatan, kafein, nikotin, dan alkohol (Munir, 2015), usia, perjalanan jauh (jet lag) dan perubahan jadwal kerja (Susanti, 2015).

Peneliti melakukan pengambilan data awal pada bulan Agustus terhadap 58 responden yang terdiri dari 10 orang laki-laki dan 48 orang perempuan. Hasil dari pengambilan data awal menunjukkan, bahwa sebanyak $41,38 \%$ responden tidak mengalami insomnia dan $58,62 \%$ responden mengalami insomnia. Dari hasil pengambilan data awal 58,62\% individu yang menderita insomnia seluruhnya berpendapat bahwa sebelumnya mereka tidak mengalami insomnia, setiap kali mereka ingin tidur mereka dapat langsung tertidur. Namun dikarenakan beban kerja yang besar, jam tidur yang tidak teratur, stres berkepanjangan, makan dan minum tidak teratur dan tidak sehat, serta kekurangan olahraga, pada akhirnya menyebabkan individu kesulitan untuk tidur meskipun memiliki keinginan yang besar untuk tidur. Sementara Mass (2002) mengemukakan bahwa hakikatnya manusia menghabiskan hampir $1 / 3$ usianya untuk tidur, keuntungan yang dapat diperoleh dari tidur yang cukup adalah individu memperoleh tenaga yang maksimal untuk memulai hari esok yang lebih prodiktif. Tidur bermanfaat untuk memulihkan, meremajakan, dan memberikan energi pada tubuh dan kognitif individu.

National Sleep Fondation (NSF) mengemukakan bahwa individu dapat meminimalisir dan bahkan menyembuhkan insomnia dengan beberapa cara salah satunya yaitu, mengatur waktu tidur dan waktu bangun di pagi hari. Pengaturan dengan menetapkan waktu tidur dan 
waktu bangun tersebut dapat membuat individu mampu meransang otak untuk berfikir tidur. Individu diharapkan mampu menenangkan diri semaksimal mungkin dengan cara menjauhkan diri dari alat elektronik, makan, minum (kafein), pekerjaan yang menguras banyak pikiran, dan lebih memilih untuk membaca bacaan yang membahagiakan atau dengan cara mendengarkan music yang tenang (Fry, 2019). Musik yang digunakan untuk mengurangi insomnia adalah musik yang memiliki efek penenang, sehingga mampu membimbing individu untuk terlelap. Weekly, Walker, Beck, Akers, dan Weaver (2018) mengemukakan bahwa nature sound membantu individu lebih tenang dan lebih rileks. Dengan mendengarkan nature sound dipercaya dapat membantu individu untuk menjadi rileks dan tidak merasakan kecemasan jika hendak memulai tidur.

Musik nature sound merupakan musik yang berbeda dengan musik yang lainnya karena tidak menggunakan alat musik untuk menciptakan suara, melainkan hanya menggunakan suara alam. Nature sound memiliki banyak manfaat untuk kesehatan manusia, baik untuk kesehatan fisik maupun psikologis. Fitri dan Andhini (2016) mengemukakan bahwa pemberian musik nature sound (suara angin dan air mengalir) pada individu yang kekurangan tidur adalah langkah intervensi yang belum banyak dilakukan namun bersifat sedatif, aman, dan mudah dilakukan, selain itu mendengarkan musik nature sound memiliki efek positif terhadap individu yang mengalami kekurangan tidur. Praag, et al (2017) mengemukakan bahwa nature sound memberikan efek relaksasi, sehingga dapat membantu menurunkan kadar insomnia. Manfaat dari nature sound juga dapat membantu individu untuk lebih santai dan nyaman. Weekly, et al (2018) mengemukakan bahwa nature sound membantu individu lebih tenang dan lebih rileks.

Wijayanti, Johan, Rochana, Anggorowati dan Chasani (2016) mengemukakan bawa musik nature sounds merupakan jenis musik temuan baru akibat moderenisasi teknologi rekaman suara, bentuk integratif musik klasik dengan suara-suara alam. Komposisi suara yang dihasilkan oleh fenomena alam, seperti angin, hujan, laut, sungai, binatang, dan burung. Suara alam dalam hal ini memiliki tempo yang berbeda, pitch, dan irama yang umumnya lambat atau nada yang tidak tiba-tiba tinggi. Sejauh ini, aplikasi nature sound yang dapat diunduh melalui android dan iphone memiliki manfaat yang baik untuk menurunkan ketegangan dan membantu individu lebih tenang, serta menjernihkan pikiran.

Berdasarkan uraian di atas dapat diketahui bahwa nature sound memberikan pengaruh terhadap penderita insomnia. Oleh sebab itu pada penelitian ini fokus kajian adalah untuk menguji pengaruh pemberian nature sound terhadap penurunan insomnia khususnya pada dewasa awal yang masih relatif jarang diteliti oleh peneliti sebelumnya. Penelitian ini diharapkan dapat berkontribusi bagi perkembangan ilmu, khususnya di dalam bidang psikologi klinis berkiatan dengan model intervensi yang dapat menurunkan gangguan insomnia.

\section{Metode}

Penelitian ini merupakan penelitian eksperimen kuasi yang menggunakan desain one group pretest-posttest. Populasi dalam penelitian ini adalah individu yang masuk dalam kategori dewasa awal yang memiliki usia 20-40 tahun dan berdomisili di kota Makassar. Teknik pengambilan sampel menggunakan purposif. Berdasarkan karakteristik yang telah ditetapkan, sampel pada penelitian ini adalah 12 dewasa awal yang memiliki usia 21-24 tahun, berstatus sebagai mahasiswa dan pegawai yang berdomisili di kota Makassar, memiliki gangguan insomnia, dan bersedia menjadi sampel pada penelitian ini. Sampel diperoleh melalui google form yang disebarkan pada media sosial.

Peneliti mengumpulkan sampel di dalam sebuah ruangan untuk melaksanakan pre-test pada hari Sabtu 14 Maret 2020. Proses pre-test termasuk dengan pemberian informed consent, skala kesehatan mental, skala Insomnia Severity Index (ISI). Pada pertemuan tersebut sampel menerima materi mengenai penelitian yang akan dilakukan, yaitu penjelasan nature 
sound dan cara mendengarkannya. Sampel juga diperkenalkan dan mendapatkan penjelasan tentang cara membuat sleep diary serta memberitahukan tujuan dari penelitian (manipulasi). Peneliti memberikan arahan untuk terus saling berkomunikasi melalui whatsapp ataupun media sosial lainya guna mengontrol jalannya proses penelitian. Sampel diberitahukan bahwa proses penelitian akan berlangsung selama tujuh hari, sehingga dalam waktu tujuh hari peneliti akan berkomunikasi dengan sampel.

Pada proses penelitian ini intervensi diberikan dengan memperdengarkan nature sound. Setiap sampel diinstruksikan untuk memilih nature sound yang mereka sukai atau yang membuat mereka merasa nyaman. Nature sound yang digunakan juga memiliki peran penting terhadap penurunan insomnia pada setiap sampel karena setiap sampel pasti memiliki kesukaan atau selera yang berbeda sehingga peneliti memberikan penawaran untuk memilih sesuai kehendak sampel. Nature sound yang sudah dipilih akan terus didengarkan hingga penelitian selesai. Durasi mendengarkan nature sound yaitu 45 menit menggunakan aplikasi white noise. Durasi 45 menit dipilih berdasarkan hasil penelitian meta-analisis yaitu dengan mendengarkan musik selama 45 menit maka tubuh akan menjadi rileks, sehingga pikiran individu dipenuhi perasaan tenang dan dapat menghilangkan stress. Dengan demikian individu akan lebih mudah untuk tertidur dengan nyenyak, (Mottaghi, Kamkar \& Mardpoor, 2015).

Teknik pengumpulan data yang digunakan peneliti yaitu menggunakan skala khusus untuk mengukur tingkatan insomnia yaitu skala Insomnia Severity Index (ISI) dari Dr. Edo Sebastian Jaya pada tahun 2012 yang merupakan hasil terjemahan dan penormaan dari skala aslinya yang diciptakan oleh Bastien, Vallieres, dan Morin (2001). Bastien, et al (2001) mengemukakan bahwa skala Insomnia Severity Index (ISI) terdiri dari lima aitem dengan tujuh pertanyaan, dan memiliki rentang nilai yaitu mulai dari angka 0-28. Semakin tinggi angka yang didapatkan dari hasil pengukuran menunjukan bahwa tingkat insomnia yang diderita semakin tinggi. Berikut adalah kategorisasi dari Skala Insomnia Severity Index (ISI):

1. 0-7 termasuk dalam kategori tidak ada gejala insomnia klinis.

2. 8-14 termasuk dalam kategori insomnia dengan status rendah.

3. 15-21 termasuk dalam kategori insomnia klinis dengan status sedang.

4. 22-28 termasuk dalam kategori insomnia klinis dengan status tinggi.

Peneliti mengontrol proses penelitian melalui sleep diary. Sleep diary juga merupakan salah satu faktor penting dalam proses pengontrolan penelitian. Sleep diary berisi tentang pengontrolan waktu tidur, seberapa sering subjek terbangun pada malam hari, waktu bangun pada pagi hari, pengontrolan mendengarkan nature sound, mengukur kualitas tidur sampel setiap hari dan mengukur seberapa baik istirahat subjek setiap hari yang dituliskan secara deskriptif. Selama proses penelitian berlangsung sampel diminta untuk mengirimkan foto sleep diary-nya dan akan mengumpulkan formnya secara langsung diakhir pertemuan, untuk kemudian diberikan post-test.

Peneliti dan sampel tidak dapat berkumpul di tempat dan waktu yang telah disepakati sebelumnya yaitu pada tanggal 21 Maret 2020, dikarenakan terjadi wabah Covid-19 sehingga mengharuskan partisiapan untuk tetap di rumah dan melakukan social distancing. Oleh sebab itu, peneliti mengunjungi rumah sampel satu persatu untuk mengumpukan sleep diary, melakukan post-test dan melakukan debriefing atau memberitahukan tujuan dari penelitian yang sebenarnya.

Teknik analisis data pada penelitian ini menggunakan uji Wilcoxon yang dapat dioperasikan melalui aplikasi SPSS 25.0 for windows. Periantalo (2017) mengemukakan bahwa uji Wilcoxon digunakan untuk melihat perbedaan pada kelompok subjek sebelum dan setelah diberi perlakuan. Tujuannya dengan melakukan Uji Wilcoxon peneliti dapat mengetahui perbedaan tingkat insomnia subjek sebelum dan setelah mendengarkan nature sound. 


\section{Hasil}

Hasil analisis data menunjukkan bahwa dari 12 sampel penelitian diketahui semuanya mengalami penurunan skor insomnia. Ditinjau dari hasil pre-test dan post-test sampel setelah mendengarkan nature sound selama tujuh hari. Berikut grafik 1 menunjukan data dari seluruh sampel.

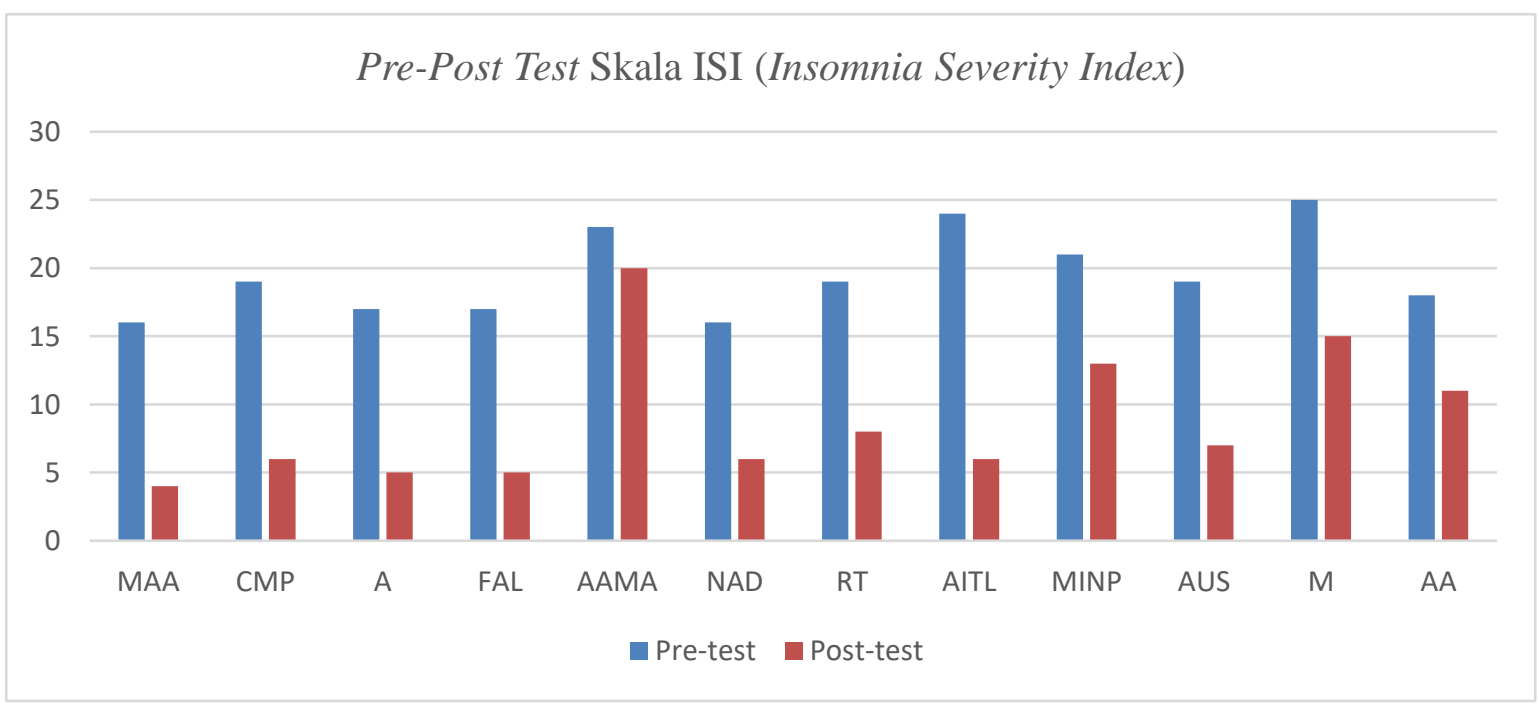

Grafik 1.

Pre- test dan Post-test Setelah Mendengarkan Nature Sound

Grafik 1 di atas menunjukkan bahwa seluruh sampel mengalami penurunan insomnia setelah dilakukannya intervensi dengan cara mendengarkan nature sound. Meskipun diantara sampel didapati beberapa orang yang mendapatkan efek kecil akan tetapi sampel tetap mengalami penurunan insomnia setidaknya satu level. Berikut pada tabel 1 adalah deskripsi kategorisasi dan jenis nature sound yang didengarkan oleh sampel.

Tabel 1.

Kategorisasi Insomnia Severity Index (ISI) Pre dan Post Test

\begin{tabular}{llllll}
\hline Nama & Nature sound & Pre-test & Kategori & Post-test & Kategori \\
\hline MAA & Amazon Jungle & 16 & Sedang & 4 & Tidak ada insomnia \\
CMP & Running Water & 19 & Sedang & 6 & Tidak ada insomnia \\
A & Beach Waves Crashing & 17 & Sedang & 5 & Tidak ada insomnia \\
FAL & Ocean Waves Crashing & 17 & Sedang & 5 & Tidak ada insomnia \\
AAMA & Water Dripping & 23 & Tinggi & 20 & Sedang \\
NAD & Beach Waves Crashing & 16 & Sedang & 6 & Tidak ada insomnia \\
RT & Rain Storm & 19 & Sedang & 8 & Rendah \\
AITL & Beach Waves Crashing & 24 & Tinggi & 6 & Tidak ada insomnia \\
MINP & Rain Storm & 21 & Sedang & 13 & Rendah \\
AUS & Boat Swaying in The Water & 19 & Sedang & 7 & Tidak ada insomnia \\
M & Camp Fire and Beach Waves & 25 & Tinggi & 15 & Sedang \\
AA & Crashing & Amazon Jungle & Sedang & 11 & Rendah \\
\hline
\end{tabular}

Berdasarkan tabel $1 \mathrm{di}$ atas dapat dilihat bahwa seluruh sampel mengalami penurunan tingkat insomnia. Sebanyak dua orang sampel mengalami penurunan dari insomnia kategori tinggi ke kategori sedang, sebanyak tiga orang sampel mengalami penurunan dari insomnia 
kategori sedang ke kategori rendah. Sebanyak satu orang sampel mengalami penurunan dari insomnia kategori tinggi ke kategori tidak ada insomnia, dan sebanyak enam orang sampel mengalami penurunan dari insomnia kategori sedang ke kategori tidak ada insomnia.

Uji hipotesis dalam penelitian ini dilakukan dengan menggunakan uji Wilcoxon. Uji hipotesis dilakukan untuk mengetahui perbedaan antara pre-test dan post-test. Uji hipotesis memiliki kriteria pengambilan keputusan yaitu jika nilai Asym.Sig.(2-tailed) < 0,05 maka Ha diterima, dan sebaliknya jika nilai Asym.Sig.(2-tailed) > 0,05 maka Ha ditolak. Berikut tabel 2 menunjukan hasil uji hipotesis dalam penelitian ini.

Tabel 2.

Hasil Uji Wilcoxon

\begin{tabular}{lll}
\hline Insomnia & Sig. & Keterangan \\
\hline Pre-Post Test ISI & 0,002 & Signifikan \\
\hline
\end{tabular}

Berdasarkan hasil analisis data yang telah dilakukan, diperoleh nilai signifikansi sebesar $\mathrm{p}=0,002(\mathrm{p}<0,05)$, berarti Ha diterima dan $\mathrm{H} 0$ ditolak. Berdasarkan hasil analisis menunjukan ada perbedaan yang signifikan antara pre-test dan post-test. Hasil penelitian ini menjelaskan bahwa ada perbedaan skor insomnia pada saat sebelum mendengarkan nature sound dengan setelah mendengarkan nature sound. Selanjutnya untuk analisis deskriptif statistik hasil penelitian ini dapat dilihat pada tabel 3.

Tabel 3.

Deskripsi Data Hipotetis Pre dan Post-test Skala ISI

\begin{tabular}{llllll}
\hline & $\boldsymbol{N}$ & Mean & Std. Deviasi & Minimum & Maximum \\
\hline Pre-test ISI & 12 & 19,50 & 3,09 & 16 & 25 \\
Post-test ISI & 12 & 8,83 & 4,91 & 4 & 20 \\
\hline
\end{tabular}

Berdasarkan pada tabel 3 tersebut di atas dapat diketahui bahwa skor maksimun skala ISI sampel sebelum mendapatkan intervensi adalah skor $_{\max }=25$ dan setelah pemberian intervensi skor maksimum ISI turun menjadi skor $_{\max }=20$. Sementara skor minum skala ISI sampel sebelum mendapatkan intervensi adalah skor $_{\min }=16$ dan setelah pemberian intervensi turun menjadi skor $_{\min }=4$.

\section{Pembahasan}

Hasil pre-test pada penelitian ini menunjukkan bahwa seluruh sampel berjumlah 12 orang memiliki tingkat insomnia pada kategori sedang hingga tinggi. Hasil post-test menunjukkan bahwa seluruh sampel mengalami penurunan insomnia setidaknya satu level kategori. Hasil dari perbandingan perbedaan pre-test dan post-test setelah diberikan perlakuan menggunakan uji Wilcoxon menunjukkan hasil signifikansi sebesar $p=0,002$ $(\mathrm{p}<0,05)$, yang artinya setelah diberikan perlakuan mendengarkan nature sound sebelum tidur sampel mengalami perubahan yang signifikan, perubahan yang terjadi adalah penurunan tingkat insomnia pada sampel. Hasil dari mean pre-test dan post-test juga mendukung hipotesis dari penelitian karena terjadi penurunan nilai mean pre-test yaitu 19,50 sedangkan mean post-test 8,83 . Hal ini membuktikan bahwa nature sound memiliki manfaat untuk membantu sampel mendapatkan tidur yang baik.

Pada penelitian ini, seluruh sampel memilih dan mendengarkan nature sound yang mereka senangi. Secara keseluruhan nature sound yang dipilih oleh sampel semuanya memiliki unsur suara kicauan burung dan suara air, baik itu air hujan, air sungai maupun ombak. Hal tersebut sesuai dengan hasil penelitian yang dilakukan oleh Amiri, Sadeghi, dan Bonabi (2017) yang mengemukakan bahwa nature sound dengan pilihan suara kicauan 
burung, suara ombak, suara hujan dan suara sungai mampu menurunkan kecemasan responden penelitian mereka secara signifikan. Begitupula Franěk, Režný, Šefara dan Cabal (2019) mengemukakan bahwa suara kicauan burung memiliki efek yang baik untuk memberikan perasaan rileks, juga rasa tentram pada individu. Suara kicauan burung juga mampu menurunkan ketegangan yang dirasakan oleh individu yang sedang dilanda ketakutan, khawatir atau sedang tergesa-gesa. Hal tersebut tentu sejalan dengan temuan pada penelitian ini, yaitu pemberian intervensi dengan cara mendengarkan nature sound sebelum tidur mampu membuat sampel menjadi lebih rileks dan siap untuk tidur.

Penelitian ini menunjukkan hasil bahwa sampel yang mendengarkan nature sound akan merasa mengantuk dan tertidur, akan tetapi sebenarnya yang terjadi adalah munculnya perasaan tenang, rileks dan perasaan amanlah yang membantu sampel dapat tertidur. Mendengarkan nature sound membantu sampel untuk menciptakan perasaan rileks sehingga membuat individu tidur dengan baik. Hal ini sesuai dengan penelitian yang dilakukan oleh Weekly, et al (2018) mengemukakan bahwa nature sound membantu individu lebih tenang dan lebih rileks.

Intervensi nature sound yang dilakukan pada penelitian ini menunjukan adanya manfaat yang besar terhadap sampel penelitian. Hal tersebut sesuai dengan yang disampaikan oleh sampel bahwa nature sound sangat membantu mereka. Bahkan sampel juga yakin bahwa kualitas dan pola tidur mereka akan benar-benar membaik jika pemberian intervensi mendengarkan nature sound dilakukan lebih lama. Oleh karena itu, dapat disimpulkan bahwa mendengarkan nature sound memiliki dampak positif untuk mengurangi tingkat insomnia yang mengganggu sampel selama ini. Sesuai dengan yang disampaikan oleh Drake, Roehrs, Roth (2003) bahwa insomnia adalah gangguan yang dapat mencegah individu untuk tidur dan mencegah individu untuk mendapatkan kualitas tidur yang baik, sehingga menyebabkan berbagai macam kerugian seperti menurunnya performa kerja, menurunnya fungsi fisik dan sosial, menurunya fungsi kognitif, memperburuk kualitas hidup dan kasus kecelakaan banyak terjadi akibat dari insomnia.

Bukan hanya dampak fisik akan tetapi dampak secara emosional juga dialami oleh seluruh sampel akibat kesulitan untuk tidur atau karena memiliki waktu tidur yang kurang, seperti stres, mudah marah, mudah sedih, atau mood yang tidak stabil. Semua dampak fisik dan emosi yang dialami sampel mengakibatkan kesulitan untuk tidur. Musabiq dan Karimah (2018) mengemukakan bahwa stres dan kecemasan memiliki efek langsung pada kesehatan secara fisik dan emosional, dampak fisik yang dihasilkan ketika stres dan cemas adalah sakit kepala, sakit perut, gangguan pencernaan, lemas, mudah sakit, sakit pada sendi, otot, dan sulit tidur. Sementara dampak emosional yang dihasilkan adalah individu lebih sensitif sehingga membuatnya mudah marah, bersedih dan khawatir.

Penurunan tingkat insomnia pada setiap sampel pada penelitian ini tidak dapat dipungkiri relatif berbeda-beda. Hal ini dikarenakan kegiatan antara subjek berbeda-beda setiap harinya, peneliti juga telah melakukan kontrol kepada setiap sampel melalui pesan singkat atau melalui telepon setiap malam selama masa penelitian berlangsung untuk mengisi sleep diary dan mendengarkan nature sound. Selanjutnya pada pertemuan terakhir bersama dengan sampel, seluruh sampel mengungkapkan bahwa mereka merasa mendapatkan perubahan dalam pola dan kulitas tidur mereka. Sampel merasa bahwa intervensi yang diberikan membantu mereka dalam mengatasi insomnia, meskipun terdapat satu individu yang merasakan dampak yang sangat besar dan terdapat satu sampel yang hanya merasakan sedikit manfaat, akan tetapi secara keseluruhan mereka semua tetap merasakan dampak positif dari mendengarkan nature sound sebelum tidur dibandingkan sebelum mendapatkan intervensi.

Hasil pengamatan berdasarkan aspek-aspek yang terdapat pada aitem-aitem skala Insomnia Severity Index (ISI), yaitu setiap individu masing-masing memililiki perubahan pada aspek-aspek tertentu. Namun demikian, secara keseluruhan dari sampel mengungkapkan bahwa mereka merasakan dampak positif pada saat mengikuti program penelitian ini, yaitu 
dengan mendengarkan nature sound. Artinya, metode mendengarkan nature sound pada penelitian ini bukan hanya untuk sekadar mendengarkan, namun juga bergantung dengan seberapa yakin sampel pada metode yang akan dijalani. Hal tersebut dikarenakan selama proses penelitian berlangsung hanya sampel saja yang mengetahui apakah sampel benarbenar mendengarkan dan memiliki kemauan yang besar untuk sembuh ataukah hanya sekedar menuntaskan tugas sebagai sampel penelitian.

Penelitian ini jauh dari sempurna, mengingat penelitian ini merupakan penelitian eksperimen lapangan, sehingga ada banyak variabel lain yang tidak dikontrol secara langsung oleh peneliti. Dengan demikian, kontrol yang minim terhadap faktor-faktor yang berpotensi untuk mempengaruhi hasil penelitian ini diasumsikan sangat besar, sehingga hasil penelitian ini hanya dapat digeneralisasikan pada sampel yang terlibat di dalam penelitian ini saja.

\section{Simpulan}

Berdasarkan hasil penelitian yang dilakukan dapat disimpulkan bahwa mendengarkan nature sound dapat menurunkan tingkat insomnia yang diderita individu, karena nature sound dapat meningkatkan perasaan rileks yang membantu individu untuk memaksimalkan kuantitas dan kualitas tidurnya. Artinya nature sound dapat dijadikan sebagai salah satu alternatif untuk meningkatkan kualitas tidur bagi individu yang mengalami insomnia. Selanjutnya, berdasarkan kelemahan dari penelitian ini, maka saran untuk peneliti selanjutnya adalah dilakukan pengkondisian dengan cara yang lebih terstruktur dan sistematis agar hasil penelitian ke depannya dapat dipastikan sebagai kontribusi dari variabel perlakuan. Diantara kontrol yang dapat dilakukan oleh peneliti di masa yang akan datang diantaranya seperti status pendidikan, status pekerjaan, usia, keadaan ekonomi, maupun kondisi kesehatan sampel ketika penelitian dijalankan. Selain itu melakukan kontrol perilaku dengan melibatkan observer untuk mengamati perilaku sehari-hari subjek selama menjalani penelitian. Melakukan perbandingan dengan dua kelompok yang berbeda seperti membandingkan kelompok nature sound dengan kelompok musik instrumen atau membandingkan dengan beberapa jenis musik lain, dan akan lebih baik jika dapat menyeragamkan volume yang digunakan ketika mendengarkan nature sound.

\section{DAFTAR PUSTAKA}

American Psychiatric Association. (1987). Diagnostic and statistical 1. Manual of Mental Disorders, Fourth Edition, Text Revision.

Amiri, M. J., Sadeghi, T., \& Bonabi, T. N. (2017). The effect of natural sounds on the anxiety of patients undergoing coronary artery bypass graft surgery. Periopertative Medicine Journal, 6(17), 1-6. https://doi.org/10.1186/s13741-017-0074-3.

Bastien., C, H., Vallieres, A., \& Morin, C, M. (2001). Validation of the insomnia severity index as an outcome measure for insomnia research. Article od Sleep Medicine. 297-307. https://doi.org/10.1016/S1389-9457(00)00065-4.

Bonnet, M. H., \& Arand, D. L. (1995). 24-Hour metabolic rate in insomniacs and matched normal sleepers. Sleep, 18(7), 581-588. https://doi.org/10.1093/sleep/18.7.581.

Curcio, G., Ferrara, M., \& Gennaro, L.D. (2006). Sleep loss, learning capacity and academic performance. Journal of Psychology, (10), 323-337. https://doi.org/10.1016/j.smrv.2005.11.001.

Drake, C. L., Roehrs, T., \& Roth, T. (2003). Insomnia causes, consequences, and therapeutics: an overview. Journal of Depression and Anxiety, (18), 163-176. https://doi.org/10.1002/da.10151.

Firdaus, H. (2018). Hubungan antara perilaku merokok dengan kecenderungan insomnia pada pekerja. Skripsi. Universitas Islam Negeri Sunan Ampel Surabaya. 
Fitri Y, E, Y., \& Andhini, D. (2016). Pengaruh terapi nature sound terhadap kualitas tidur pada pasien dengan sindroma koronaria akut. Jurnal Keperawatan Sriwijaya, 3(1), 30-39.

Ford, D. E., \& Kamerow, D. B. (1989). Epidemiologic study of sleep disturbances and psychiatric disorders: an opportunity for prevention? Jama, 262(11), 1479-1484. https://doi.org/10.1001/jama.1989.03430110069030.

Franěk, M., Režný, L., Šefara, D., \& Cabal. J. (2019). Effect of bird songs and traffic noise on pedestrian walking speed during different season. Research Article, 1-28. https://doi.org/10.7717/peerj.7711.

Johnson, E. O., Roth, T., Schultz, L., \& Breslau, N. (2006). Epidemiology of DSM-IV insomnia in adolescence: lifetime prevalence, chronicity, and an emergent gender difference. Pediatrics, 117(2), e247-e256. https://doi.org/10.1542/peds.2004-2629.

Katz, D. A., \& McHorney, C. A. (1998). Clinical correlates of insomnia in patients with chronic illness. Archives of internal medicine, 158(10), 1099-1107.

Kozier et al. (2004). Fundamentals of nursing consepts, proces, and practice. New Jersey: Pearson Prentise Hall.

Maas, J.B. (2002). Power sleep. Bandung, Indonesia: Kaifa.

Maslim, R. (2013). Diagnosis gangguan jiwa, rujukan ringkas PPDGJ-III dan DSM 5. Jakarta, Indonesia: Nuh Jaya.

Mottaghi, R., Kamkar, A., \& Mardpoor, A. (2015). The effectivenes of targeted music theraphy intervention and symptoms of insomnia disorder in seniors. The International Journal of Indian Psychology, 4(2). https://doi.org/10.25215/0204.104.

Munir, B. (2015). Neurologi dasar. Jakarta, Indonesia: Sagung Seto.

Musabiq, S. A., \& Karimah, I. (2018). Gambaran stress dan dampaknya pada mahasiswa (Description of stress and its impact on students). Jurnal Ilmiah Psikologi, 2(20), 75-83.

National Institutes of Health. (2005). National Institutes of Health State of the Science Conference statement on manifestations and management of chronic insomnia in adults, June 13-15, 2005. Sleep, 28, 1049-1057.

Fry, A. (2019). Step to do when you insomnia. Retrieved from https://www.sleepfoundation.org/articles/stress-and-insomnia

Periantalo, J. (2017). Validitas alat ukur psikologi: aplikasi praktis. Yogyakarta, Indonesia: Pustaka Pelajar.

Potter, P., Perry, A., Ross-Kerr., \& Wood, M. (Eds). (2006). Canadian fundamentals of nursing. (3rd ed.). Toronto: Harcourt Canada.

Praag,G.V., Casandra, D., Garfinkel, Sarah, N., Sparasci., Oliver., Mees., Alex., Philippides., Andy, O., Ware., Mark., Ottaviani., Chrsitina., Critchley., \& Hugo, D. (2017). Mind-wandering and alterations to default mode network connectivity when listening to naturalistic versus artifical sounds. Scientific Reports, 7(1), 1-12.

Roth, T. (2007). Insomnia: definition, prevalence, etiology, and consequences. Journal of clinical sleep medicine, 3(5 suppl), S7-S10. https://doi.org/10.5664/jcsm.26929.

Sateia, M. J., Doghramji, K., Hauri, P. J., \& Morin, C. M. (2000). Evaluation of chronic insomnia. An American Academy of Sleep Medicine review. Sleep, 23(2), 243-308.

Sathivel, D., \& Setyawati, L. (2017). Prevalensi insomnia pada mahasiswa fakultas kedokteran $\begin{array}{llll}\text { universitas } & \text { Udayana. Intisari } & \text { 8ains } & \text { Medis, 8(2), }\end{array}$ https://doi.org/10.15562/ism.v8i2.119.

Stepanski, E., Zorick, F., Roehrs, T., Young, D., \& Roth, T. (1988). Daytime alertness in patients with chronic insomnia compared with asymptomatic control subjects. Sleep, 11(1), 5460. https://doi.org/10.1093/sleep/11.1.54.

Susanti, L. (2015). Faktor-faktor yang mempengaruhi kejadian insomnia di poliklinik saraf RS DR. M. Djamil Padang. Jurnal Kesehatan Andalas, 4(3), 951-956. doi: https://doi.org/10.25077/jka.v4i3.391. 
Weekly, T., Walker, N., Beck, J., Akers, S., \& Weaver, M. (2018). A review of apss for calming, relaxation, and mindfulness interventions for pediatric palliative care patients. Journal of Children, 5(16). https://doi.org/10.3390.

Wijayanti, K., Johan, A., Rochana, N. Anggorowati., \& Chasani, S. (2016). Musik suara alam terhadap penurunan kecemasan pada pasien kritis. Jurnal Keperawatan dan Pemikiran Ilmiah, 2(3), 1-10. https://doi.org/10.30659/nurscope.2.2.20-29. 